\title{
Writing a Research Paper for Journal of Nepal Agricultural Research Council
}

\author{
Bal Krishna Joshi ${ }^{1 @}$, Tek Bahadur Gurung ${ }^{2}$, Jiban Shrestha ${ }^{3}$ and Hari Krishna Upreti ${ }^{4}$ \\ ${ }^{1}$ National Agriculture Genetic Resources Center (Genebank), NARC, Khumaltar, PO Box 3055, Kathmandu; @: \\ joshibalak@yahoo.com, iD http://orcid.org/0000-0002-7848-5824 \\ ${ }^{2}$ Nepal Agricultural Research Council, Singhadurbar, Kathmandu; <tek_fisheries@hotmail.com> \\ ${ }^{3}$ National Commercial Agriculture Research Program, Pakhribas, Dhankuta, Nepal; <jibshrestha@gmail.com> \\ ${ }^{4}$ Communication, Publication and Documentation Division, NARC, Khumaltar; <hariupreti2077@gmail.com>
}

Received 24 Aug 2017, Accepted 5 Jan 2018, Published 28 April 2018

Copyright $@ 2018$ NARC. Permits unrestricted use, distribution and reproduction

in any medium provided the original work is properly cited.

\begin{abstract}
Agricultural research findings are required to reach soon to the farmers, extensionists, media, researchers, policy makers, businessperson, students, teachers and so many other stakeholders. Among different types of publications, research paper is generally published in journal considered as standard type of publication in term of quality and recognition. Most of the journals follow similar pattern and framework; however, the style, format and process may be different with each other. A research (scientific) paper is a written describing original research result using standard methods and materials. The major sections in a journal paper are abstract, introduction, materials and methods, results, discussion, conclusion, and references. Accordingly Journal of Nepal Agricultural Research Council has its own style and format. Author needs to follow guidelines strictly on the use of punctuation marks such as comma (,), period (.), space, justification etc; otherwise submitted manuscripts could be immediately return to author without considering in review process. In general, we received manuscripts with many errors on citation and references, poor elaboration of results of experiments, weak discussion, missing to acknowledge funding agencies, submitting non-editable figures, very few numbers of citations of Nepalese researchers, statements not in logical order, etc. In general, the scientific papers should be written in simple way with new but sufficient justification backed up by data in the form of tables, graphs, flow diagrams etc so that readers can understand easily with high readability. The submitted manuscript in the journal office are sent to two to three reviewers for specific recommendation on the originality of the work, appropriateness of the approach and experimental design, adequacy of experimental techniques, soundness of conclusions and interpretations, relevance of discussion and importance of the research. The language clarity and organization of the article are also asked with the reviewers. In response to reviewer's comments all authors are expected to reply each and every comments and suggestions of reviewers, if such comments and suggestion are not acceptable, the author/s can argue for their points, if genuine. Here in this paper we described detail contents of each section along with style and format for a research paper writing targeted to Journal of Nepal Agricultural Research Council.
\end{abstract}

Keywords: Error and mistakes, Format and style, Review, Submission, Writing a paper

\section{सारांश}

कषि अनुसन्धानका उपलब्धिहरु जत सक्दो छिटो र सरल तरिकाले कषक, प्रसारणकर्ता, अनुसन्वानकर्ता, ब्यापारी, विधार्थी, नीति नियम निर्मातक, शिक्षक, आदि समक्ष पग्नु पर्दछ। विभिन्न किसिमका प्रकाशनहरु मध्ये अनुसन्धानमुलक लेख साधारणतया जर्नलमा छापिन्छ र जर्नललाई सबैभन्दा राम्रो र गुणात्मक मानिन्छ। जर्नलहरुको प्राय जसो उस्तै रुपरेखा र तौरतरिका भएपनि style, format र प्रकाशन गर्ने नियम फरक हुन्छ, । अनुसन्धान लेखमा मौलिक उपलान्धिहरु जुन निश्चित प्रबिधि र वस्तु प्रयोग गरिन्छ, लेखिन्छ। लेखमा हुने मुख्य खण्डहरुमा सारांश, परिचय, बिधि र वस्तु, उपलब्धि, छलफल, निचोड र सन्दर्भ सामग्री पर्दछ । लेखकले जर्नलको guidelines पूर्ण रुपमा हेर्नुपई र साना साना कुरामा जस्तै खालीठाउँ, कमा (,), थोप्ला (.), आदिमा पनि ध्यान दिनुपछ। Guidelines अनुसार नभए लेख तुरन्त फिर्ता गरिन्छ। लेखहरु प्राप्त गर्दा मुख्य तया सन्दर्भ सामग्रीमा, छलफलमा, चित्रमा, आफनै देशको लेखको प्रयोगमा, रकम प्राप्त संस्थाको नाममा र सिलसिला मिलाउने क्रममा धेरै कमि कमजोरी र गल्तिहरु भेटीन्छ। अनुसन्धान लेख लेख्दा साधारण भाषामा, पढ़दा सजिलै बुकिने, तथ्यांकको आधारमा मुख्य उपलब्धिहरु, तालिका, चित्र आदिको प्रयोग गरिन पई । प्राप्त लेख दुई वा तिन जना समिक्षकलाई पठाइन्छ। समिक्षकले विभिन्न आधार जस्तै भाषा, मौलिकता, अनुसन्धान बिधि, तथ्यांक विश्लेषण, समिक्षा, महत्व, प्रयोग तथा प्रभाव पर्न सक्ने आदिको पक्षमा हेरी सुकाव दिन्छ उक्त सुकाबहरु लेखकले संलग्न गरि जति सक्दो छिटो पठाउनुपछ। समीक्षकको प्रत्येक बुँदालाई समेटेको हुनुपई। यस लेखमा नार्क जर्नलको लागि लेख कसरी लेख्ने भन्ने बिषयमा छलफल गरिएको छ।

\section{INTRODUCTION}

Publication is the last step of any scientific research process. Each and every step of research along with results should be published which helps to advance the technology and principles. Researchers should publish so that others can benefit from their contribution to understand the recent progression on understanding of the newest 
knowledge in the world. There are many journals venue and types. Different publishers of journals have their different publication policy, guidelines, and scope.

Nepal Agricultural Research Council (NARC) publishes different types of materials namely Brochure, Booklet, Leaflet, Factsheet, Annual report, Newsletter, Book, Book chapter, Proceedings and Journal. Among these publication, Journal is the most important and standard publication of NARC. NARC forms Editorial Team and has its own publication guidelines.

Nepal Agricultural Research Council (established in 1991) publishes two journals annually. The first one is Nepal Agriculture Research Journal which is published in collaboration with Society of Agricultural Scientists, Nepal (SAS-N, established in 1995) since 1997. It is abbreviated as Nepal Agric. Res. J. It is an annual publication and latest volume is 14 published in 2014. Second journal is Journal of Nepal Agricultural Research Council (commonly called NARC Journal) which is abbreviated as J. Nepal Agric. Res. Counc. The NARC started this journal to publish from 2015. It is an annual publication, targeting to publish at NARC day, (Baisakh 25 or in the month of April) in each year. Its website is http://narc.gov.np/narc-journal/. The target audience or subscribers of NARC Journal are researchers, farmers, policy makers, businessperson, students and teachers.

\section{NARC JOURNAL AND FEATURES}

NARC journal prefers original research articles, review paper, research note, concept paper and crop registration manuscripts. Main features of this journal are: ISSN (International Standard Serial Number), (print and online), DOI (Digital Object Identifier) number to each published paper, on line availability through NARC and NepJol websites (with open access policy), and indexed in more 27 databases. All manuscripts are checked for plagiarism, if any. The scientific editors, generally the senior expert's names are mentioned in each paper. The NARC may provide cash incentives for reviewers and editorial members.

The major headings in research paper for NARC Journal are Title, ABSTRACT, INTRODUCTION, MATERIALS AND METHODS, RESULTS, and DISCUSSION with conclusion as last paragraph, ACKNOWLEDGMENTS and REFERENCES. Basic features of these sections are described in Table 1. In writing these sections, every sentence should convey the exact truth as simply as possible.

Table 1. Question for each section where author need to answer

\begin{tabular}{|c|c|c|c|c|c|}
\hline SN & Section & Question & Tense & Voice & Major content \\
\hline 1 & Abstract & $\begin{array}{l}\text { Summary of the } \\
\text { whole paper within } \\
8-10 \text { sentences }\end{array}$ & Past & Active & $\begin{array}{l}\text { Starting with a line for concept, } 1-2 \text { sentences } \\
\text { devoted for objective of the study, then how the } \\
\text { author/s materialize the study (Materials and } \\
\text { Methods). The next } 2-5 \text { sentences will describe } \\
\text { the results of the study, then } 1-2 \text { lines may be on } \\
\text { statistical descriptions, Finally in discussion it } \\
\text { would be desirable to mention about the } \\
\text { implication of the findings, etc }\end{array}$ \\
\hline 2 & Introduction & $\begin{array}{l}\text { Why did you do this? } \\
\text { (context and aim) }\end{array}$ & $\begin{array}{l}\text { Present } \\
\text { and past }\end{array}$ & Active & $\begin{array}{ll}\text { - } & \text { Nature and scope of the problem } \\
\text { - } & \text { Literature review (generally with latest } \\
\text { - } & \text { publication would be preferred) } \\
\text { - } & \text { Objective }\end{array}$ \\
\hline 3 & $\begin{array}{l}\text { Materials and } \\
\text { Methods }\end{array}$ & $\begin{array}{l}\text { What did you do? } \\
\text { (methods) or How } \\
\text { the problem was } \\
\text { studied? }\end{array}$ & Past & Active & $\begin{array}{ll}\text { - } & \text { Materials } \\
\text { - } & \text { Procedures } \\
\text { - } & \text { Statistical design } \\
& \text { Mention about the treatment and replicates. } \\
& \text { Parameters measuring methods and tools }\end{array}$ \\
\hline 4 & Results & $\begin{array}{l}\text { What did you find? } \\
\text { (core results) }\end{array}$ & Past & Active & $\begin{array}{ll}\text { - } & \text { Findings } \\
\text { - } & \text { Table } \\
\text { - } & \text { Figure } \\
& \text { Describe minimum, maximum and mean } \\
\text { values of the parameters measured in the } \\
\text { experiments. Avoid giving the reasons and } \\
\text { conditions }\end{array}$ \\
\hline 5 & Discussion & $\begin{array}{l}\text { What does this } \\
\text { mean? (Interpretation } \\
\text { in context) or What } \\
\text { the results mean? }\end{array}$ & $\begin{array}{l}\text { Past and } \\
\text { present } \\
\text { (for } \\
\text { generally } \\
\text { accepted }\end{array}$ & Active & $\begin{array}{ll}\text { - } & \text { Research problem and major findings } \\
\text { - } & \text { Meaning and importance } \\
\text { - } & \text { Relate } \\
\text { - } & \text { Alternative explanations } \\
\text { - } & \text { agricultural relevancy }\end{array}$ \\
\hline
\end{tabular}




\begin{tabular}{|c|c|c|c|c|c|}
\hline SN & Section & Question & Tense & Voice & Major content \\
\hline & & & $\begin{array}{l}\text { facts and } \\
\text { principle } \\
\text { s) }\end{array}$ & & $\begin{array}{ll}\text { - } & \text { Limitations } \\
\text { - } & \text { Suggestions }\end{array}$ \\
\hline 6 & Conclusion & $\begin{array}{l}\text { What is this good } \\
\text { for? (application) or } \\
\text { How the work } \\
\text { advances the field } \\
\text { from the present state } \\
\text { of knowledge }\end{array}$ & $\begin{array}{l}\text { Past and } \\
\text { future }\end{array}$ & Active & $\begin{array}{ll}\text { - } & \text { Take-Home Message } \\
\text { - } \quad \text { Way forward }\end{array}$ \\
\hline 7 & $\begin{array}{l}\text { Acknowledgm } \\
\text { ent }\end{array}$ & $\begin{array}{l}\text { Who supportedand } \\
\text { what? }\end{array}$ & Past & Active & $\begin{array}{l}\text { Funding source, contributors and areas of } \\
\text { contributions }\end{array}$ \\
\hline 8 & References & $\begin{array}{l}\text { What paper you } \\
\text { reviewed, what are } \\
\text { the recent papers } \\
\text { available in this } \\
\text { topics? }\end{array}$ & $\begin{array}{l}\text { Not } \\
\text { applicable }\end{array}$ & $\begin{array}{l}\text { Not } \\
\text { applic } \\
\text { able }\end{array}$ & Relevant, recent references, national expertise \\
\hline
\end{tabular}

\title{
TITLE
}

Title should be informative and unique started with key word but concise and clear and should reflect the content of the paper. Do not use abbreviated and shortcut word/s, use only common name, do not write scientific name. It should be an informative summary of the paper. Select the words in a title carefully for clarity and accuracy. Long titles are unappealing to readers. Shorter titles may not be sufficiently specific, and therefore not sufficiently informative. A title should be a label, not a sentence. Consider more than one title, and ask colleagues which one is a better description of your paper. We need running title, which is generally composed of 4-6 words for header.

\section{AUTHORS AND ADDRESS}

Journal demands full names along with family name. No abbreviated names, however, middle name can be of only initial letter. Write complete addresses of the authors at the time of the work reported in the paper. Indicate current or postal addresses as a footnote on the first page of the paper, if the address is different from workplace. Indicate the corresponding author using superscript symbol @. Use numbering superscript for linking address. Give email address of all authors at the end of address. If there are many authors from same address, write email within 〈> after initials eg BKJ<joshibalak@yahoo.com>, TBG<tek_fisheries@gmail.com>. All authors should review the manuscript carefully before submission for positive outcomes.

\begin{abstract}
State the essence of the paper. It should be concise and clear without any cited references, tables and figures, highlighting rationale, objectives, materials and methods, important results and conclusion (suitable for direct reproduction in some abstracting journals). Be very succinct - a single paragraph, not more than 250 words. Editors frequently decide to accept or reject a paper (and readers decide to read it completely or not), after only reading the abstract. Write in the past tense. Information from any published source can be written in the present tense. Information not stated in the paper should never be given in the abstract. Do not use abbreviations unless they are commonly accepted terms. Write an abstract after you have completed and finalized the entire paper. Abstract should also be in Nepali language using Preeti font.
\end{abstract}

\section{KEYWORDS}

There should not be more than 5 keywords. Consider single word or phrase. It should be helpful to search (related to materials and methods, results). They are the words or terms that characterize the main domains to which the paper pertains. Order alphabetically and capitalize each word.

\section{INTRODUCTION}

Include short introduction to justify the research and relevant reviews and state the objectives clearly. Make sure that the reader knows enough to appreciate the relevance of the work and why it is appropriate to ask the question. Consider following points (general to specific): a. Nature and scope of the problem, b. Literature review, c. Rationale (reasons why the study was carried out), d. Objective, If possible give the hypothesis, research question and e. an outline of how the research was performed, and the reasons for selecting a particular method. Include only important references, define specialized terms on first mention. Do not use uncommon abbreviations and give their full form on the first mention. Ensure your introduction with continuous flow of 
information and ideas. In total, this section should give the most recent knowledge on the subject matter you are addressing with the gaps to pierce ahead for progression.

\section{MATERIALS AND METHODS}

Include description of materials, procedures and statistical design used as well as method to analyze data so that a peer can repeat the procedure. Describe in detail for new methods and only reference for methods developed by earlier researchers (diagram, algorithm, equation, and table). Report the study location or site/s, geo-references (altitude, latitude and longitude, etc) and date of experiment conducted. Write scientific name with authority, common and local name of an organism, if possible with chromosome number as Oryza sativa $\mathrm{L}$. $(2 \mathrm{n}=2 \mathrm{x}=24)$. For materials considered following 3 important points: Exact technical specifications, Quantities, and preparation method and source. Try to make sub-headings of this section consistent with that of result. M\&M descriptions should be simple, write in the past tense following time sequence with work done and should be reproducible.

\section{Statistical Methods}

In all experiment and data based papers statistical analysis must be pertinent and thorough enough to ensure the accuracy of the conclusions. Degree of freedom and level of certainty should be reported in order to facilitate evaluation of conclusions. This is very important part. Report enough details of experimental design. A multiple comparison procedure useful when treatments consist of a set of unrelated materials (such as cultivars or chemicals), but may be inappropriate in other cases. When treatments are factorial their effects may be classified by partitioning into main effects and interactions. Specific relationships among treatments may be elucidated with single-degree-of-freedom contrasts (for further consult Joshi et al 2002 J. Institute Sci. Tech. 12:69-81). Regression analyses are appropriate when treatments form a progressive series of an experimental factor.

\section{RESULTS}

Present in a concise manner avoiding data that are already given in Tables and Figures. Present analyzed data (only meaningful) in the form of figures, tables, and/or descriptions of observations. Mention the least, the highest and mean values of measured parameters without any interpretation here in this section. Figures are preferred to tables, and tables are preferable to straight text. Do not draw conclusions and reserve data interpretation for the discussion. Write clearly in the past tense. Only those variables that affect results should be given in tables or graphs. Write concisely, for example do not use the statements such as 'it is clearly shown in Figure 3 that the rate of growth related to temperature' but may use 'rate of growth related on temperature (Figure 3). Common mistakes in this section are inclusion of unnecessary data and their double presentation, eg repeated in a table or a figure as well as within the text.

\section{DISCUSSION}

In this section, author needs to explain all of their observations as much as possible, focusing on mechanisms Followings could be the major content in sequence in this section.

- Reiterate the research problem, methods/ state the major findings

- Explain the meaning and importance of the findings why findings are important by interpreting your data doing this articulate your figures and tables numbers used in the text for clarity by citing into the text in the Discussion section

- Relate the findings to those of similar studies

- Consider alternative explanations of the findings (all possible explanations), reasoning and argument

- State the agricultural relevance of the findings

- Acknowledge the study's limitations

- Make suggestions for further research and give the take-home message in the form of a conclusion

Decide if the experimental design adequately addressed the hypothesis, and whether or not it was properly controlled. Finally, where do you go next? The best studies open up new avenues of research. What questions remain? Did the study lead you to any new questions? Try to think up a new hypothesis and briefly suggest new experiments to further address the main question. Be creative, and don't be afraid to speculate. Refer to work done by specific individuals (including yourself) in past tense. Refer to generally accepted facts and principles in present tense. The conclusion, recommendation and possible impact (if any) should be based on the supporting data

\section{ACKNOWLEDGEMENTS}

Acknowledge for significant technical help received from others, grants, fellowships or other financial assistance. Do not thank someone without identifying the nature of the assistance; do not thank peer reviewers and someone just for inspiration 
or senior, chief, etc. Format for writing name of person is full name, initial with period for middle name and last name (eg Arjun K. Katuwal) followed by affiliation (Renuka Shrestha, Agronomy Division). It is not necessary to prefix by $\mathrm{Dr}$, Mr or Ms.

\section{REFERENCES}

List only the papers closely related to the authors' work. Include up to-date references showing that you are aware of recent research and have taken this into account. Three common mistakes found in references and their citations (all waste the editor's time and increase the likelihood of rejection) are:

a. Not all the citations in text are listed in the references and not all the references are cited in the text,

b. No uniformity in the presentation of references and

c. Incomplete information given about the references. To avoid missing references (or text citations) make a careful cross-check on the final draft of your paper before submission. All finalized references must be converted to the journal style.

\section{SOFTWARE FOR REFERENCE STYLE AND FORMAT}

We found very difficult to keep references and citation style and format error free. Editorial team recommends to follow referencing software as reference manager. This is a software tool for publishing and managing bibliographies, citations and references. Some are Zotero (https://www.zotero.org/), Mendely (https://www.mendeley.com/), Refworks (www.refworks.com), Endnote (http://endnote.com/), etc. Zotero and Mendely are free software and easy to handle. They have many user-friendly features. Zotero help you collect, organize, cite, and share your research sources (Figure 1). It has Zotero Plug-in for Word which has features of auto insert citation, insert references automatically, choose journal style, easy to build reference database. One can access Zotero from anywhere and has sync facility after log in to retrieve won database from anywhere. After completing referencing in the paper, edit manually in accordance with journal format and style. Editorial team is planning to develop one module based on the Zotero for NARC Journal for managing references.

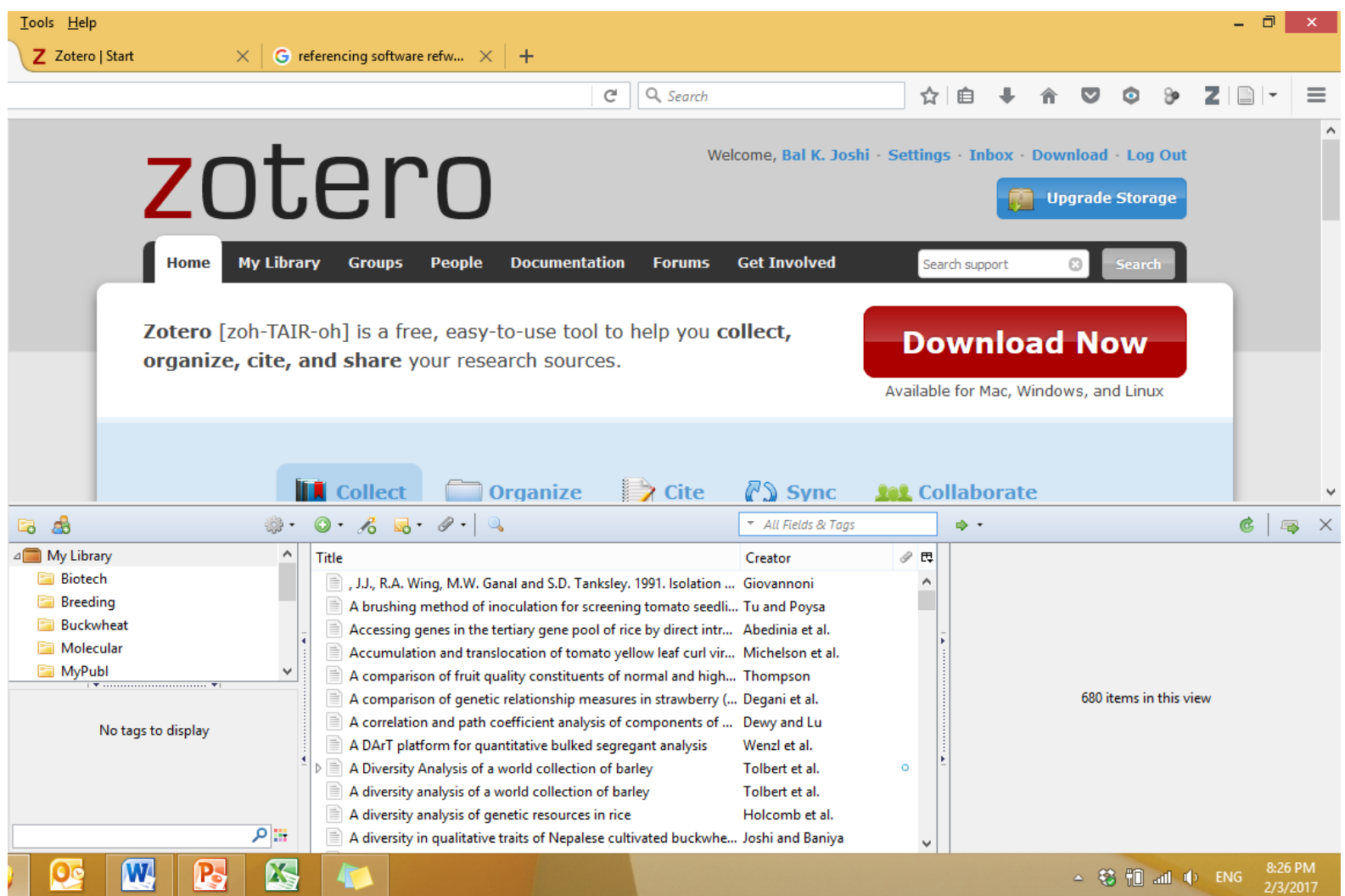

Figure 1. Screenshot of Zotero web and Zotero app.

\section{STYLE AND FORMAT}

Follow instruction to authors which is available at http://narc.gov.np/narc-journal/author-guidelines/ or in latest issue of the journal. It should be A4 size, single space, no auto space for headings + paragraph (before and after) + captions, MS-Word, everything with normal text and para (no auto format except said). Capitalize initial of each key words in title and capitalize headings, capitalize initial of each key words in sub-headings. Capitalize initial letter of Table and Figure. Bold all headings and sub headings. Use and instead of \&. Do not use period (.) 
in very common abbreviations for example eg, etc, et al, ie, Rs. All years should be in English calendar and write single year, not two years as 2015/16. Generally harvesting time determines the year. Do not provide space before percentage sign of any value $(67 \%)$ and use word per or symbol (/ mostly in Table and Figure) not superscript. Italicize non-English words and scientific name and it should be followed by authority and genetics (eg Oryza sativa L., 2n=2x=24). Use Times New Roman with 14 font size for title, 10 for general text, 9 for abstract, keywords, Table, Figure, acknowledgment and references. Do not keep any things in text box. Header and footer, foot note or Table foot note and source should be italicized with 8.5 font size.

\section{Citation in Text}

There should be last names of the authors for up to two authors (eg Shrestha 2015, Gurung and Shrestha 2011), last name of the first author followed by et al for more than two authors (eg Singh et al 2014) followed by the year of publication within parenthesis. No italics and period for et al (Thapa et al 1997), do not use comma (,) before year (Ghimire 2012), period (.) in et al, eg, etc, ed, eds and initials of author name and sort citation by year of publication.

\section{References}

You should separate family name and year by comma (,). Do not give space between two initials of author name and in between volume and page numbers, do not justify, give 0.3 " hanging indent to each reference list, capitalize each key word for book, proceedings, workshop, etc. For more than one publication by the authors in the same year, the publication should be numbered as (a) and (b) of that year with the earliest publication the year being designated (a) and so on. Each reference should contain first author's family name followed by his/her first initial and middle name (initial only) and the co-author/s with initials of first and middle names followed by family name, year of publication (English calendar), title of article, name of journal or name and place of publisher (in case of book), volume number and page numbers. If no authority is available for citation, credit the work to the publisher. Some examples are, Yuan LP, ZY Yang and JB Yang. 1994. Hybrid rice in China. In: Hybrid rice technology: New Development and Future Prospects (SS Virmani, ed). IRRI, the Philippines, pp.143-147.Joshi BK, S Gyawali and DS Poudyal. 2002. Regression analyses and multiple comparison procedures: Uses and misuses. J. Institute Sci. Tech. 12:69-81.

In case of Nepali Language References, first write authors' name and year in English and write title in Roman. Remaining parts eg publisher, address, page number, etc are same as other publications and at last write In Nepali language) within parenthesis. For example, Khatri BH, BP Luitel and D Chaudhary. 2015. Nepalma haal samma unmochit ra pangikrit aaluka jaat haru: Ek chhoto parichaya. National Potato Research Program, NARC, Khumaltar, Lalitpur.

\section{Table and Figure}

Each Table should be numbered with proper title heading. Sort table appropriately, use symbols for footnotes in the order shown:, $\dagger, \ddagger, \S, \uparrow, \#, \dagger \dagger, \ddagger \dagger$, etc. The single $(*)$ and double asterisks $(* *)$ are used to indicate statistical significance, 5 and $1 \%$ levels of significance, respectively. Do not repeat information in the text presented in charts or graph. Use 9 font size, bold word Table and column headings with only horizontal lines. Each Figure and/or graph should be numbered with the proper title heading. Figure/picture should have good color combination so it can be printed well in black and white. Use 9 font size and bold word Figure, use period (.) at the end of caption. Figure should be drawn without boarder. Provide Figure both in Word and Excel format. Do not abbreviate Figure as Fig. Font size within Figure should be 8.5.

\section{Time and Date}

Use 12-hr time system with four digits eg 02:30 pm. Write date in the format DD/MMM/YYYY eg 7 Aug 2000. Page limit for a paper is 12 typed pages in single space including Tables, Figures and References.

\section{REVIEWING YOUR PAPER}

We recommend reviewing carefully your paper before submitting; make sure the methodology has no flaws; make sure the results and conclusions are accurate; make sure the literature review is meaningful and comprehensive and make sure the text is clear, without grammatical or syntactical errors. It is good to have a break of a few days before the final revision. Poor presentation (form and/or content) will frustrate the reviewers. Author can ask for someone to review and comment on your paper. During proofread, author should read section headings, all numbering (sections, equations, tables, figures, etc), captions, reference list, in-text citations, typos, grammar, writing sequence, writing style, etc. 


\section{SUBMISSION AND REVIEW PROCESS}

Before submission, we suggest to visit journal webpage (Figure 2) at www.narc.gov.np and read all information eg Author Guidelines, Ethical Guidelines, Copyright Form, Editorial Board and Submission, etc.

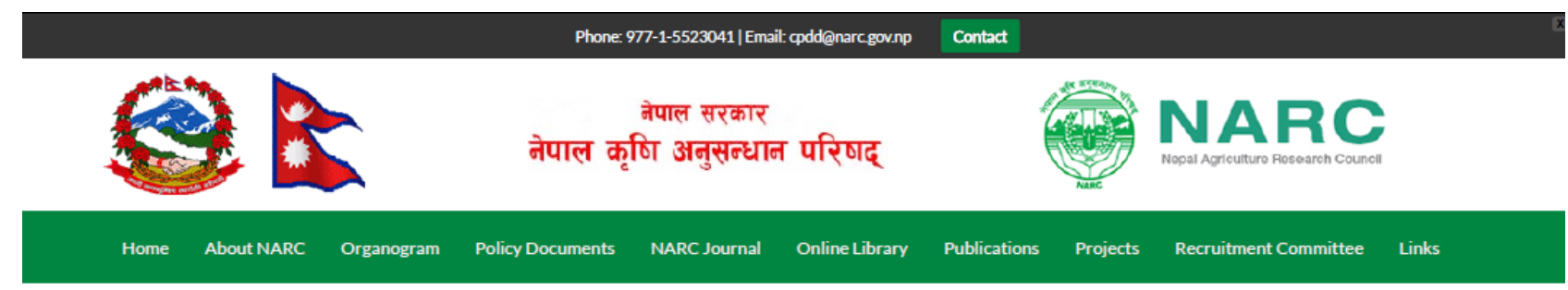

\section{NARC Journal}

\begin{tabular}{|c|c|c|c|c|c|c|c|}
\hline $\begin{array}{c}\text { About the } \\
\text { Journal }\end{array}$ & $\begin{array}{c}\text { Aim and } \\
\text { Scope }\end{array}$ & $\begin{array}{c}\text { Abstracting } \\
\text { and Indexing }\end{array}$ & $\begin{array}{c}\text { Author } \\
\text { Guidelines }\end{array}$ & $\begin{array}{c}\text { Author } \\
\text { Index }\end{array}$ & $\begin{array}{c}\text { Ethical } \\
\text { Guidelines }\end{array}$ & Copyright Form & Editorial Board \\
\hline Submission & $\begin{array}{c}\text { Current } \\
\text { Issue }\end{array}$ & $\begin{array}{c}\text { Previous } \\
\text { Issue }\end{array}$ & $\begin{array}{c}\text { Reviewer } \\
\text { Guidelines }\end{array}$ & Reviewers & $\begin{array}{c}\text { Peer Review } \\
\text { Process }\end{array}$ & Journal contact & FAQs \\
\hline
\end{tabular}

Journal of Nepal Agricultural Research Council

ISSN print: 2392-4535, ISSN online: $2392-4543$

DOI Prefix: $10.3126 /$ jnarc

Frequency: One Issue per Year

Website: http://narc.gov.np/narc-journal/

Submission Email: cpdd@narc.gov.np, narcjournal@gmail.com

\section{About the Journal}

Journal of Nepal Agricultural Research Council is an official publication of Nepal Agricultural Research Council, Kathmandu, Nepal. It is a peer reviewed open access journal that publishes articles written in English from all over the world in all aspects of agricultural research particularly in the field of agronomy, plant breeding, horticulture (vegetable/fruit science, spices, beverages, floriculture), entomology, plant pathology, soil science, animal science (Pasture and forage, breeding, nutrition, health), fisheries and aquaculture, agro-forestry, weed science, food science, seed science, agricultural engineering, agricultural environment, agricultural botany, agricultural economics, agricultural ecology, agro biodiversity, post-harvest technology, agriculture policy, market, socio-economics, outreach and agri-extension education. All submissions will be checked by iThenticate before publication of manuscripts. The journal is published in both print and

online versions is available for free. Each paper published in this journal is assigned a DOI number.
Search

CODON: JNARC

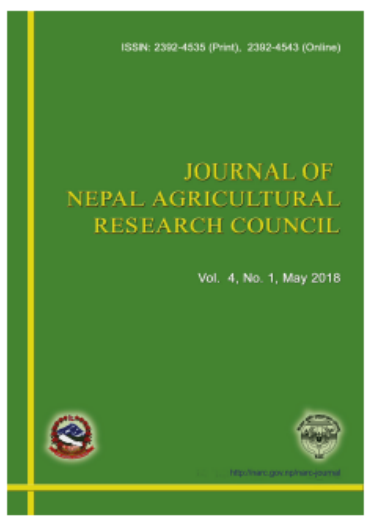

Vol. 4, No. 1, 2018 Coming Soon

Editor-in-Chief Tek Bahadur Gurung, PhD Principal Scientist Nepal Agricultural Research Council Kathmandu, Nepal Email: tek_fisheries@hotmail.com

Figure 2. Screenshot of NARC Journal webpage.

Submission and review process are depicted in Figure 3. Anyone can submit paper any time to managing editor at cpdd@narc.gov.np or narcjournal@gmail.com. Submit your paper on time after carefully looking on check list. We expect cover letter where author need to friendly introduce your paper to the editors, briefly and boldly state why think your paper deserves to be published (importance to the development of the field) and name and address of two potential reviewers. Managing editor review paper immediately after submission for scope of the paper, style and format followed by author in writing a paper. If it is not followed author's guidelines, paper is returned without any process and delay. Author need to follow strictly author's guidelines and resubmit. If paper is ok for scope, style and format, it is registered giving unique name to the file and sent to two peer reviewers. Generally number and keywords are considered for naming the file. Anyone should not change file name, however, one can add any words. Among the two reviewers, one may be a member of Editorial Team and another may be an external. We send paper to reviewers along with guidelines, rubric and covering letter. Reviewers' names are kept confidential to authors.

\section{Plagiarism}

The practice of taking someone else's work or ideas and passing them off as one's own is now a day common mainly because of cut pastes system available through the websites. There should not be zero plagiarism, however, some percentage of plagiarism (eg around 20\%) with correct citation are allowed. Author can check themselves at http://www.plagiarism.org/plagiarism-101/what-is-plagiarism/or other apps. Editorial team checks 
plagiarism randomly with authenticated plagiarism software. Authors and readers should read ethical guidelines available at journal webpage. Some of non-ethical works are writing papers in field other than own academic and/ or research fields. Contributions of all researchers should be considered and strictly there should not be a paper written with using other's data, text or reports.

\section{Reviewers' Perspective}

Generally we send paper to two experts for review. They generally look on the importance of the research, originality of the work, appropriateness of the approach and experimental design, adequacy of experimental techniques, soundness of conclusions and interpretations, relevance of discussion, clarity of presentation and organization of the article and English composition, etc.

\section{Post Review: Notification}

Reviewers send annotated paper and their comments along with rubric to editor. Managing editor inform author with status of acceptance, acceptance subject to minor revisions, acceptance subject to major revisions or rejection. Author need to work on the comments the earliest the possible. Don't feel disappointed/angry/offended if your paper is rejected.

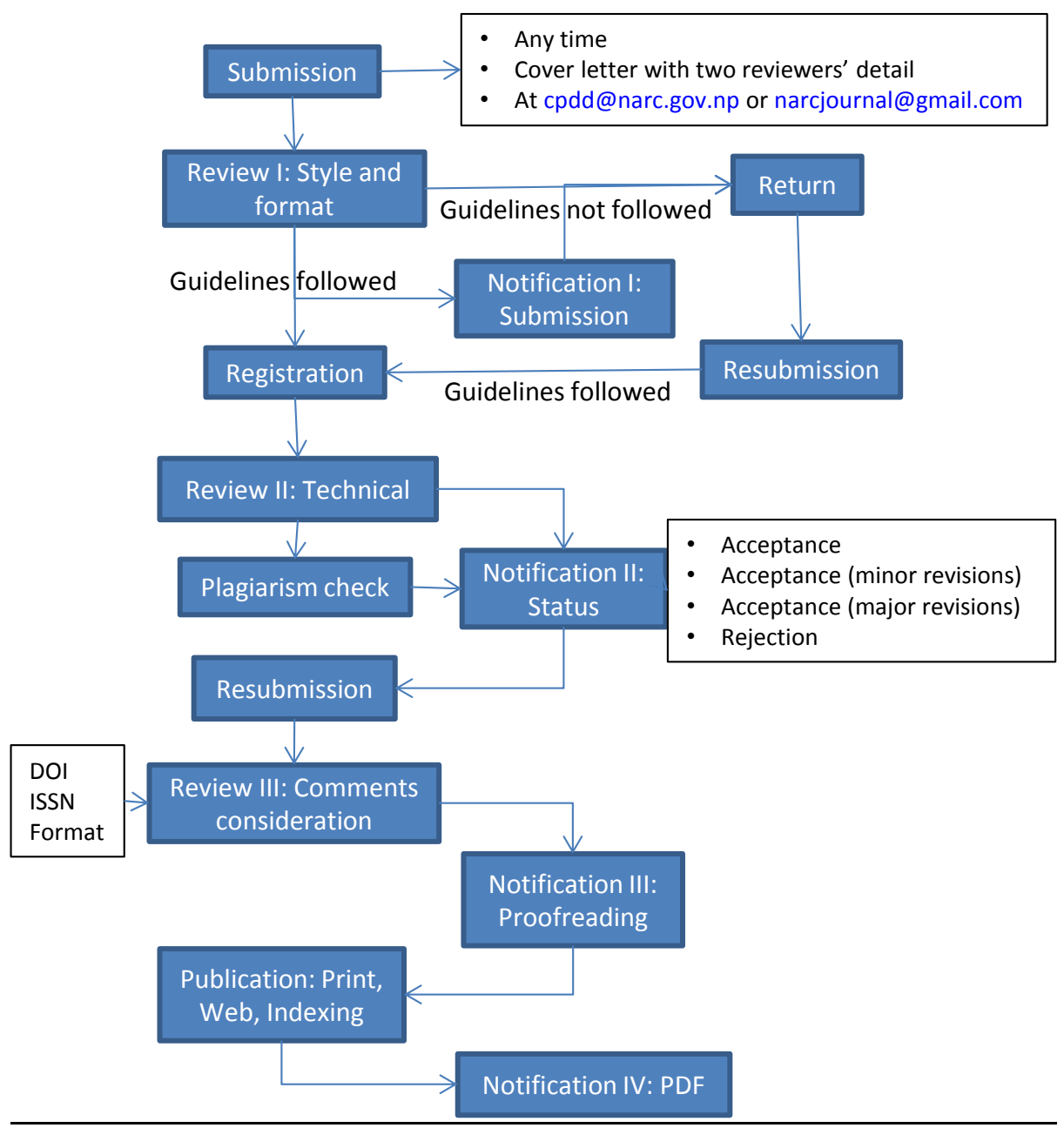

Figure 3. Paper publication process in NARC Journal.

\section{Why Rejection}

Main reasons of rejection are irrelevant topic; work not sufficiently original; original methodology but results not good enough; low acceptance rate; theme doesn't cover the journal's scope; shallow, uncritical literature review; methodology lacks rigor; poor analysis of results, experimentation, etc; bad science in general and bad writing quality and presentation, etc. 


\section{Post Review: Resubmission}

Corresponding author must address the reviewers' comments. For this, read carefully the editor's letter, answer all the questions and address all the recommendations, either major or minor, write the summary of revisions, clearly presenting your answers to every single question raised by the reviewers. It is not good to take a defensive attitude towards the reviewers' recommendations. If you don't agree with some aspect, present your arguments objectively in the summary of revisions.

\section{Proofreading}

After editing and typesetting your article, the editor will send it to you for proofreading. Author need to read carefully through the article and correct technical, spelling and grammatical errors and make sure your main points have not been lost to editing. This is last opportunity you have to make minor corrections on your article and make your corrections on the article and return it to your editor promptly to meet the journal's publication deadline. If you are late you may need to wait for the next issue.

\section{GENERAL MISTAKES AND ERRORS}

During review process, we have noticed many mistake and errors. Some of them are: Writing a year with indication of two years eg 2014/15, writing date following Nepali calendar, pasting figures as picture which is not editable, different font size, style in figures, making fancy figures and poor color matching for printing black white, not submitting excel data files. In citation there are many misuse of separators eg. Adhikary, 2015; Gurung et al., 2015; Shrestha 2016; Anonymous 2009; TB Gurung, Personal Communication (Tek B. Gurung 2016 Personal Comm.); Source, MoAD 2008, etc. Some authors use same font size to all sections. We found many times errors on using space, period, comma, brackets, semi colon and asterisk. Translating Nepalese nouns (Bitter for Tite, Local for Sthaniya) are also common mistake. Other mistake is to justify paper title, caption, references, note, source, etc.

Very old research findings are also considered by authors. Full name and complete address with email of all authors are not provided. Space and symbol for corresponding author are not properly used.

Keywords are not alphabetically sorted and use small letter for a word after semi colon. Sometimes, they use key words separately. Abstract is not written in Nepali language following Preeti font. Results and discussion are kept together and there are many repetitions with very poor discussion.

Very common mistake in references section are in use of space, comma, period, bold, initial capital letter, scientific name, indent, sorting. Some references are very old and some are cited without listing full references and vice versa. There are many errors in spelling of authors and error on year in citation and references list. Some references are incomplete and generally Nepalese literatures are not properly listed. It is general to ignorance national references.

\section{BRIEF GUIDELINES}

Do not format other than in instruction guidelines. Auto number rows in Table and sequencing numbering for Table and Figure are necessary. Table by appropriate column heading, keywords and references should be sorted. Author need to check spelling and grammar, font type, size, capital letter/ word, bold, italics, etc. We expect active voice, informative paper having strong visual impact and easy to understand. It is good to see the submission check list. Do not italicize scientific name if they are headed by Scientific name.

\section{PUBLICATION}

CPDD print journal and distribute relevant person and organizations. Each author will get pdf file of their paper and can download from website. Journal detail and full papers will be published on-line as well at NARC website (http://narc.gov.np/narc-journal/) and at NepJol (http://www.nepjol.info/index.php/JNARC). Publication will also

be notified through social media, ie $y$ f $\square$ in Scholar, JournalTOCs, J-Gate, Publons, NARC Library, NepJOL (INASP), ResearchGate, SCOPUS Elsevier (In the process), TEEAL and 13 universities libraries database namely Columbia University Libraries, Iowa State University Libraries, University of Edinburgh Library, Western Sydney University Library, University of New Mexico Library, Renmin University of China Library, York University Library, Gent University Library, University of Toronto Libraries, Harvard Library, Kent State University Libraries, Cornell University Library and University of Minnesota Catalog. 


\section{FUTURE PLAN}

Submission, review and notification systems will be on-line. There will be referencing software for NARC Journal basically developed based on Zotero (https://www.zotero.org/). Editorial team encourages authors to cite papers published in NARC Journal for getting impact factor. Color text for headings, sub headings, citation, Tables and Figures need to consider for making pdf reader easy and attractive. Different color should be selected so that one can print using black and white printer. In case of many papers, additional issue can be published. Journal may be paper free in future.

\section{REFERENCESANDFURTHERREADING}

Barker A and F Manji. Writing for change. http://www.fahamu.org.uk/WFCEng/.

Byrne DW. 1998. Publishing your medical research paper: What they don't teach in medical school. Williams and Wilkins, Baltimore.

CBE. 1994. Scientific style and format. Council of Biology Editors. Cambridge University Press Cambridge.

Day RA. 2004. How to write and publish a scientific paper. $5^{\text {th }}$ ed, Oryx Press. www.inasp.info/psi.

Huth EJ. 1998. Writing and publishing in medicine. $3^{\text {rd }} \mathrm{ed}$, Lippincott Williams and Wilkins, Baltimore.

International Committee of Medical Journal Editors. Uniform requirements for manuscripts submitted to biomedical journals. http://www.icmje.org.

Iverson C, A Flanagin, PB Fontanarosa, RM Glass, P Glitman, JC Lantz, HS Meyer, JM Smith, MA Winker, MA and RK Young. 1998. American medical association manual of style: A guide for authors and editors. $9^{\text {th }}$ ed, Williams and Wilkins, Baltimore.

Joshi BK, MP Upadhyay, HP Bimb, D Gauchan and BK Baniya. 2005.Data analysis methods adopted under in-situ global project in Nepal. Nepal Agric. Res. J. 6:99-109. http://www.narc.org.np/publicaton/pdf/journal/Vol6/data_analysis_methods_adopted_under_situ_global_project.pdf

Joshi BK, S Gyawali and DS Poudyal. 2002. Regression analyses and multiple comparison procedures: Uses and misuses. JIST 12:69-81. http://sites.google.com/site/jafgaubase/publication/journal-1

Joshi BK. 2005. Guide for scientific paper writing. Nepal Agric. Res J. 6:131-137. http://www.narc.org.np/publicaton/pdf/journal/Vol6/guide_for_Scientific_Paper_Writing.pdf

Joshi BK. 2005. Statistical guidelines. Nepal Agric. Res J. 6:138. http://www.narc.org.np/publicaton/pdf/journal/Vol6/statistical_guidelines.pdf

Lang TA and M Secic. 1997. How to report statistics in medicine: Annotated guidelines for authors, editors and reviewers. American College of Physicians, Philadelphia.

NARC and SAS.2005 .Details Guide for Writing Articles to Nepal Agric. Res. J. Nepal Agric. Res. J. 6:122-129.

NARC. 2016. Instruction to authors. Nepal Agricultural Research Council, Kathmandu. Journal of Nepal Agricultural Research Council, http://www.narc.gov.np/narc/narc_journal.php.

SSC. 2000. Informative presentation of tables, graphs and statistics. SSC. The University of Reading, UK.

WHO. 1998. WHO editorial style manual. World Health Organization, Geneva.

Zell HM. 1998. A handbook of good practice in journal publishing. $2^{\text {nd }}$ ed. The International African Institute and African Books Collective, London and Oxford.

\section{Useful Websites}

APA reference style - although the book is only available in print for sale, this website gives examples of references in APA style - very useful. http://www.english.uiuc.edu/cws/wworkshop/

Citations - useful guide on how to cite internet (online) publications. http://www.apastyle.org/elecsource.html

Cordova S. How to write a scientific paper. New Mexico Junior Academy of Science. http://www.nmas.org/JAhowto.html

Smart P and J Falaiye. How to publish your research work. This resource is available on the INASP website. www.inasp.info/psi or www.inasp.info/pubs

INASP Resources on website.www.inasp.info/psi/resources

Mainali KP, Editor, Himalayan Journal of Sciences, Kathmandu, Nepal. www.himjsci.com

Notes on the Structure of a Scientific Paper: These guidelines were prepared with the aid of Robert Day's entertaining book How to write and publish a scientific paper (ISI Press, Philadelphia, 1979).

http://aerg.canberra.edu.au/pub/aerg/edupaper.html Instructions for authors and http://www.mco.edu/lib/instr/libinstq.html Connects you to the instructions for authors of hundreds of biomedical journals.

SciDevNet. How do I write a scientific paper? http://www.scidev.net/ms/howdoi/index.cfm

Writing styles for humanities: http://www.kyvl.org/html/ref/subwriting.shtml. This website gives a wide range of links to websites detailing how to write papers in different humanities areas. 